See discussions, stats, and author profiles for this publication at: https://www.researchgate.net/publication/8064379

\title{
Particulate Organic Matter in the Sea: The Composition Conundrum
}

Article in AMBIO A Journal of the Human Environment · January 2005

DOI: 10.1639/0044-7447(2004)033[0565:POMITS|2.0.CO;2 · Source: PubMed

\section{CITATIONS}

158

3 authors:

Cindy Lee

Stony Brook University

185 PUBLICATIONS 12,585 CITATIONS

SEE PROFILE

Q. Carol Arnosti

University of North Carolina at Chapel Hill

256 PUBLICATIONS 5,187 CITATIONS

SEE PROFILE

Some of the authors of this publication are also working on these related projects:

PROOF-PECHE View project

Selfish Activity in Marine Bacteria View project
340 PUBLICATIONS 18,835 CITATIONS

SEE PROFILE 


\section{Particulate Organic Matter in the Sea: The Composition Conundrum}

As organic matter produced in the euphotic zone of the ocean sinks through the mesopelagic zone, its composition changes from one that is easily characterized by standard chromatographic techniques to one that is not. The material not identified at the molecular level is called "uncharacterized". Several processes account for this transformation of organic matter: aggregation/disaggregation of particles resulting in incorporation of older and more degraded material; recombination of organic compounds into geomacromolecules; and selective preservation of specific biomacromolecules. Furthermore, microbial activities may introduce new cell wall or other biomass material that is not easily characterized, or they may produce such material as a metabolic product. In addition, black carbon produced by combustion processes may compose a fraction of the uncharacterized organic matter, as it is not analyzed in standard biochemical techniques. Despite these poorly-defined compositional changes that hinder chemical identification, the vast majority of organic matter in sinking particles remains accessible to and is ultimately remineralized by marine microbes.

\section{INTRODUCTION}

The sinking of particulate material from surface to deeper waters is a major pathway for transporting carbon and other biologically-associated elements within the ocean. Material exported from the euphotic zone leaves as large, fast-sinking particles, and constitutes a source of food for pelagic and benthic organisms. A variety of biological, physical and chemical processes alter the organic composition of particles as they sink. Organic compounds synthesized in the surface ocean are consumed by heterotrophic zooplankton and bacteria that remove most of the organic matter in the surface waters before it can be exported below the euphotic zone. The majority of exported organic matter is remineralized to $\mathrm{CO}_{2}$ on its way to the sea floor. Despite this great loss, the surface productivity signal can extend to the deep-sea floor and into the sediments, and remnants of a phytoplankton source are reflected in the composition of organic matter there. Organic biomarkers have been used to investigate the sources of organic matter; similarly, specific diagenetic indicator compounds have been used to ascertain the extent of organic matter degradation. Use of organic indicators is limited, however, by labile compounds being preferentially lost with depth, while the proportion of total organic carbon that is chemically uncharacterizable at the molecular level (not easily recognizable as a specific compound by standard techniques) increases with depth and makes up most of the bulk carbon in sediments. The origin, lability and fate of this uncharacterized organic material have been the subject of considerable recent research and even more speculation.
Vertical fluxes of organic carbon through the water column vary temporally and spatially, generally as a function of the physical forcings that influence biological production $(1,2)$. Fluxes of individual classes of biochemicals out of the surface ocean also directly reflect local production (3-5). These flux-productivity relationships for specific organic compounds typically are much more variable than for total organic carbon alone, reflecting their greater sensitivity to foodweb dynamics, source and other factors. Although virtually all primary production is limited to the euphotic zone, chemosynthesis to form new organic matter from $\mathrm{CO}_{2}$ can occur in areas of the water column with low oxygen and in hydrothermal vent environments $(6,7)$. Individual compounds can also be synthesized from other compounds through alteration reactions, resulting in local maxima (of products) or minima (of precursors). There exists, in addition to the spatial correlation of particle flux with primary productivity, a well-defined temporal relationship. Close temporal coupling between phytoplankton blooms and particle flux maxima in the underlying water column clearly indicates rapid downward transport of biogenic debris $(4,8-10)$.

Fluxes of specific organic compounds generally decrease with depth due to dissolution, disaggregation and heterotrophic consumption by zooplankton and bacteria $(11,12)$. Regardless of the location in the ocean, two trends are observed: $i$ ) the flux of organic matter reaching the sea floor is a tiny fraction of primary production; and ii) there are two zones of intense organic matter remineralization, the epipelagic zone and the benthic boundary layer. Comparisons of particle rain rates at various depths over the entire marine water column clearly demonstrate that typically $<$ $1 \%$ of the organic matter produced by phytoplankton in the surface ocean reaches the sea floor in the open ocean $(1,13$, 14). The preferential removal of certain components from sinking particles with depth leads to major changes in the organic composition of the particles. Decomposition and transformation mechanisms, rates and extent vary depending on the molecular structure of individual compounds and their availability as substrates for heterotrophic metabolism $(5,11)$. Measurements of individual compounds indicate that flux attenuation factors in the upper water column are consistent with the biochemical stability of different compound classes. There is also strong evidence that organic matter/mineral-matrix association provides a strong secondary control on the fate of both the inorganic and organic phases of particles as they sink through the ocean $(15,16)$. Sinking particles include the biogenic mineral phases of planktonic diatoms, radiolaria, foraminifera, coccolithophorids, and pteropods and lithogenic minerals (e.g. from dust); these minerals may serve as dense ballast to allow the particles to sink. Sinking speed in turn influences the profile of organic matter remineralization with depth and the effectiveness of the deep ocean as a carbon sink. The deeper that 


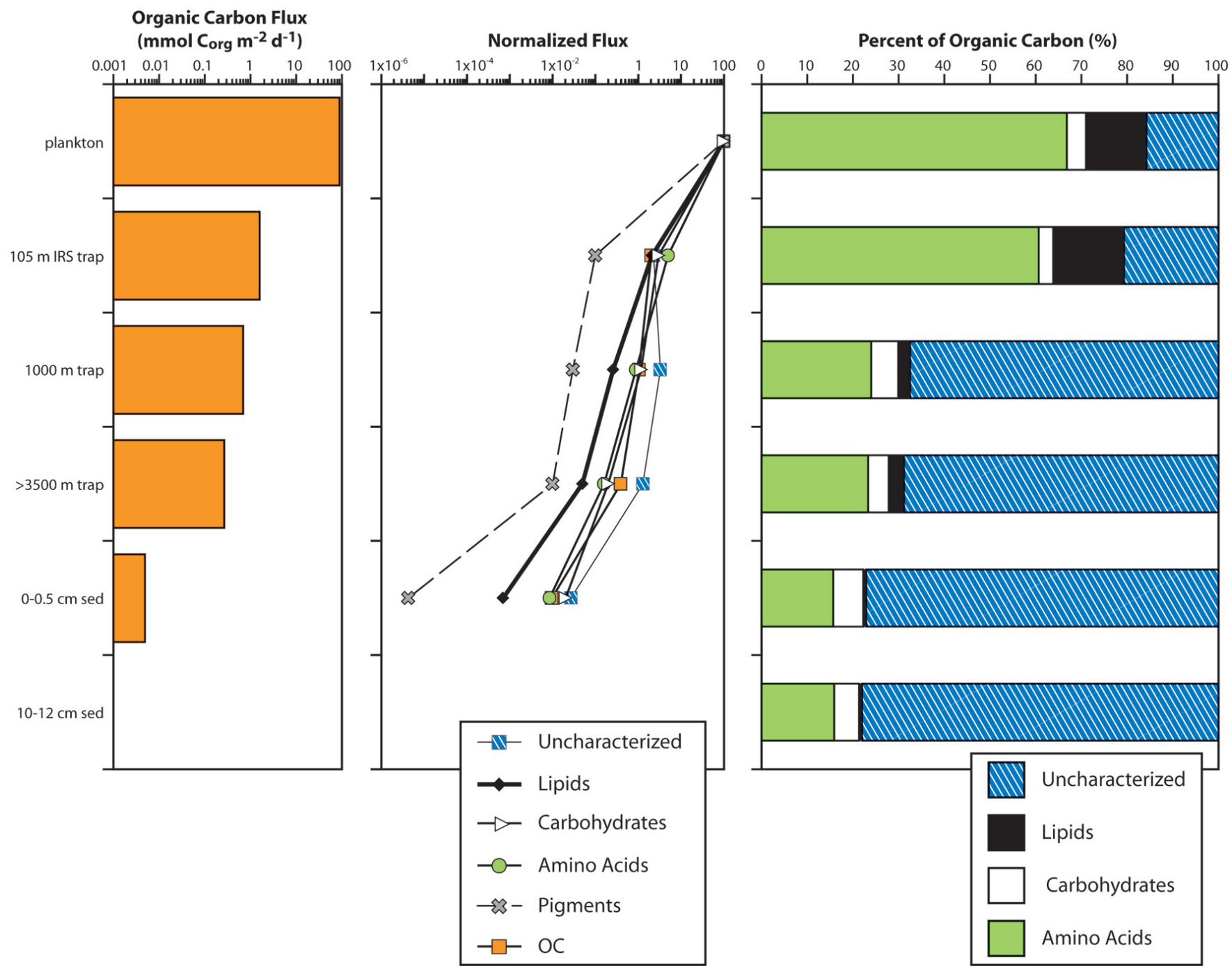

Figure 1. Left panel: Flux of organic carbon (mmol $\mathrm{C}_{\text {org }} \mathrm{m}^{-2} \mathrm{~d}^{-1}$ ) for plankton, sediment trap, and surface sediments in the equatorial Pacific Ocean. Center panel: Fluxes of $\mathrm{OC}$ and compound classes, normalized to the production by plankton, to show relative losses down the water column. Right panel: Individual chromatographically-determined biochemicals were converted to carbon equivalents and compared to total organic carbon to show how much OC was present in the major biochemical classes (amino acid, carbohydrate and lipid) and thus, by difference, how much remains uncharacterized at the molecular level. Chlorines were also measured but were an insignificant fraction of the total. Data from Wakeham et al. (11).

remineralization occurs, the longer recycled carbon is kept from contact with surface waters and the atmosphere.

Although we now know much about the origin and fate of particulate organic matter gained from specific compound distributions, we know relatively little about the molecularlevel organic composition of a large fraction of the organic matter in seawater, marine particles and sediments (17). Even recent attempts at molecular characterization of particulate organic matter fail to identify a significant fraction of the total carbon demonstrating the inadequacy of current analytical tools and the need for new ones. The substantial decrease in the amount of organic carbon that may be easily identified at the molecular level is illustrated in a sea surface-to-sediment study in the equatorial Pacific Ocean that showed an increase in uncharacterized organic matter with increasing water column depth (Fig. 1) (11). In phytoplankton, most of the organic matter ( $>80 \%$ of OC) consisted of amino acids, carbohydrates and lipids that could be efficiently characterized at the molecular level with conventional chemical hydrolysis and chromatographic methods. Particles exported from the euphotic zone contained only a slightly lower proportion of molecularly-characterizable material. The major decrease in molecularly-characterized material occurred in the mesopelagic zone (200-1000 m depth), even though the larger relative decrease in flux was in the euphotic zone. In fact, there was an absolute increase in uncharacterized material between these depths suggesting either that uncharacterized material was being produced from characterized material, or that it was being incorporated from the surrounding water column. The percentage of characterized organic matter in sinking particles continued to decrease down the water column becoming a minor component in the sediments $(<$ $20 \%$ of OC), while the amount of material that remained molecularly-uncharacterized increased concurrently and became the major fraction $(>80 \%)$ of OC in sediments. Below we discuss the composition of particulate organic matter at various depths in the ocean, and the processes (Fig. 2) that are responsible for the fact that portions of it are not easily characterized by the standard analytical methods used to date.

Particles in the ocean are part of a size continuum that includes dissolved and colloidal molecules as well as suspended and sinking particles (Fig. 3). The differentiation between these fractions is discussed in more detail elsewhere (18). 


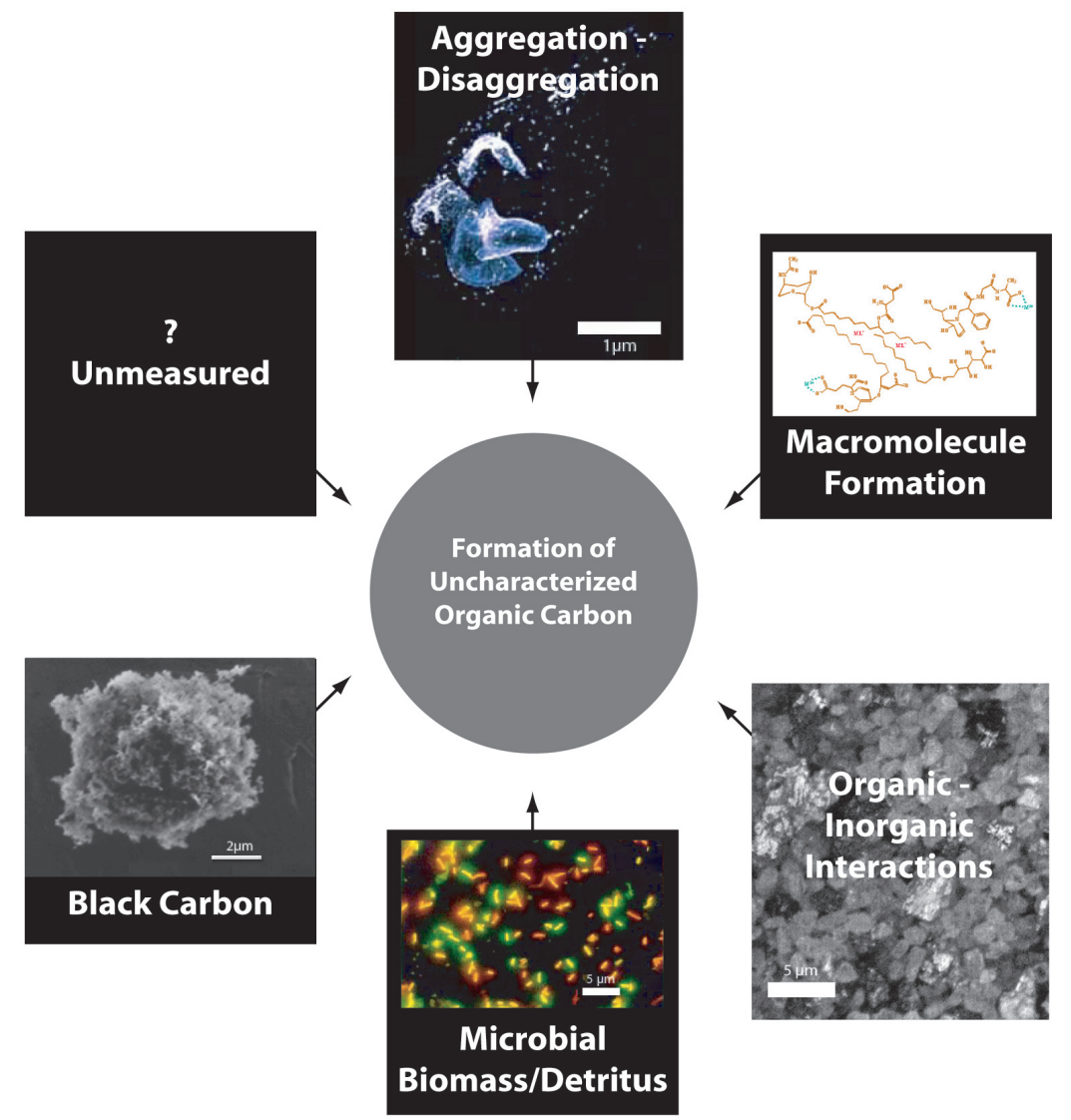

Figure 2. The formation of uncharacterized organic matter in the ocean water column may be affected by several complementary processes, including aggregation and disaggregation, formation of bio- and geo-macromolecules, interactions between organic substances and inorganic mineral matrices, production of organic materials in the form of microbial biomass or detritus, black carbon, and the fact that some organic materials are simply not routinely measured.

Here we concentrate primarily on sinking particles, those generally larger than about $50 \mu \mathrm{m}(19,20)$. Most particles are of course much smaller, but directly contribute little to the sinking flux.

\section{COMPOSITION OF MOLECULARLY-CHARACTER- IZED PARTICULATE ORGANIC MATTER}

Just as primary productivity affects the amount of particulate material sinking in the ocean, the predominance of compounds derived from phytoplankton, and to a lesser extent zooplankton, influences the composition of organic matter in sinking particles, some of which ultimately reaches the sea floor. The composition of this particulate and sedimentary organic matter can vary significantly depending on its original source matter and subsequent alteration reactions $(5,21)$. The fact that some small fraction of the original particulate organic matter composition is preserved, albeit selectively, is the basis of using "molecular biomarkers" as indicators of the source of sedimentary organic matter. The great number and chemical diversity of biomarkers among the biochemicals typical of living organisms provides a fingerprint that can be used to infer sources of organic matter (22), assuming we understand how compositions are altered in the water column and surface sediments.

Although phytoplankton producers dominate the organic composition of sinking particles in surface waters, heterotrophic consumers can substantially alter this composition through selective degradation and alteration reactions. Not only can organic compounds be selectively consumed, but also alteration products, which include a structural portion of the original compound, can be left behind. High relative percentages of nitrogen and carbon in the form of chromatographically-measured amino acids $(3,12)$ and carbohydrates $(23,24)$ are generally indicative of relatively undegraded organic remains. Many individual compounds can be used to indicate the freshness or diagenetic state of organic matter. Many can also suggest the type of organism (zooplankton or microbe) that was responsible for degradation.

Certain labile phytoplankton constituents, such as polyunsaturated fatty acids, are readily degraded in the environment and/or herbivore guts, and thus are depleted in moredegraded particles. Preferential loss of labile algal fatty acids leading to an enrichment of more stable components in the products of heterotrophic metabolism has been observed in field studies $(11,25)$ and laboratory feeding experiments $(26,27)$. Organic matter alteration via zooplankton degradation is also seen in the production of chlorophyll degradation products, particularly the formation of pheophorbide (28). Similar alteration reactions during zooplankton grazing hydrolyze the algal carotenoid esters, fucoxanthin and peridinin, to the corresponding alcohols fucoxanthinol and peridininol (29). These four compounds (fucoxanthin, peridinin, fucoxanthinol and peridininol) are the major carot-

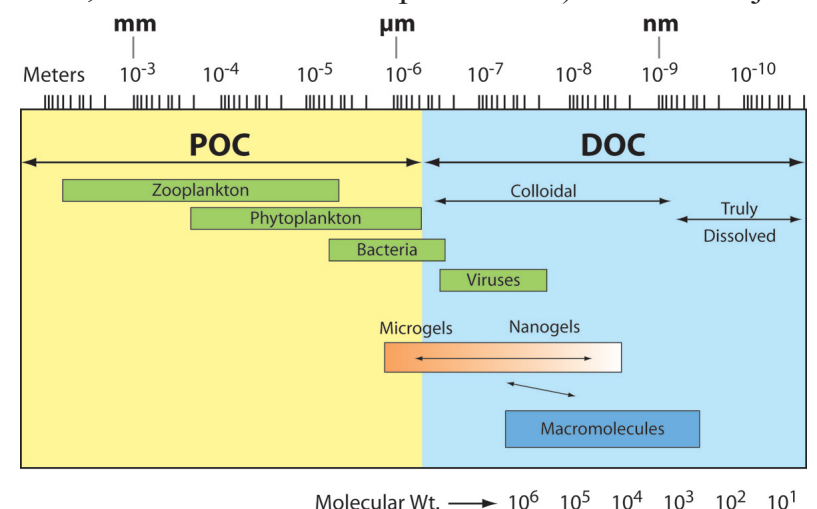

Figure 3. Size continuum of organic matter, particulate and dissolved, in the ocean and analytical tools that may be used in collecting and characterizing the nature of these materials. After Verdugo et al. (18). 


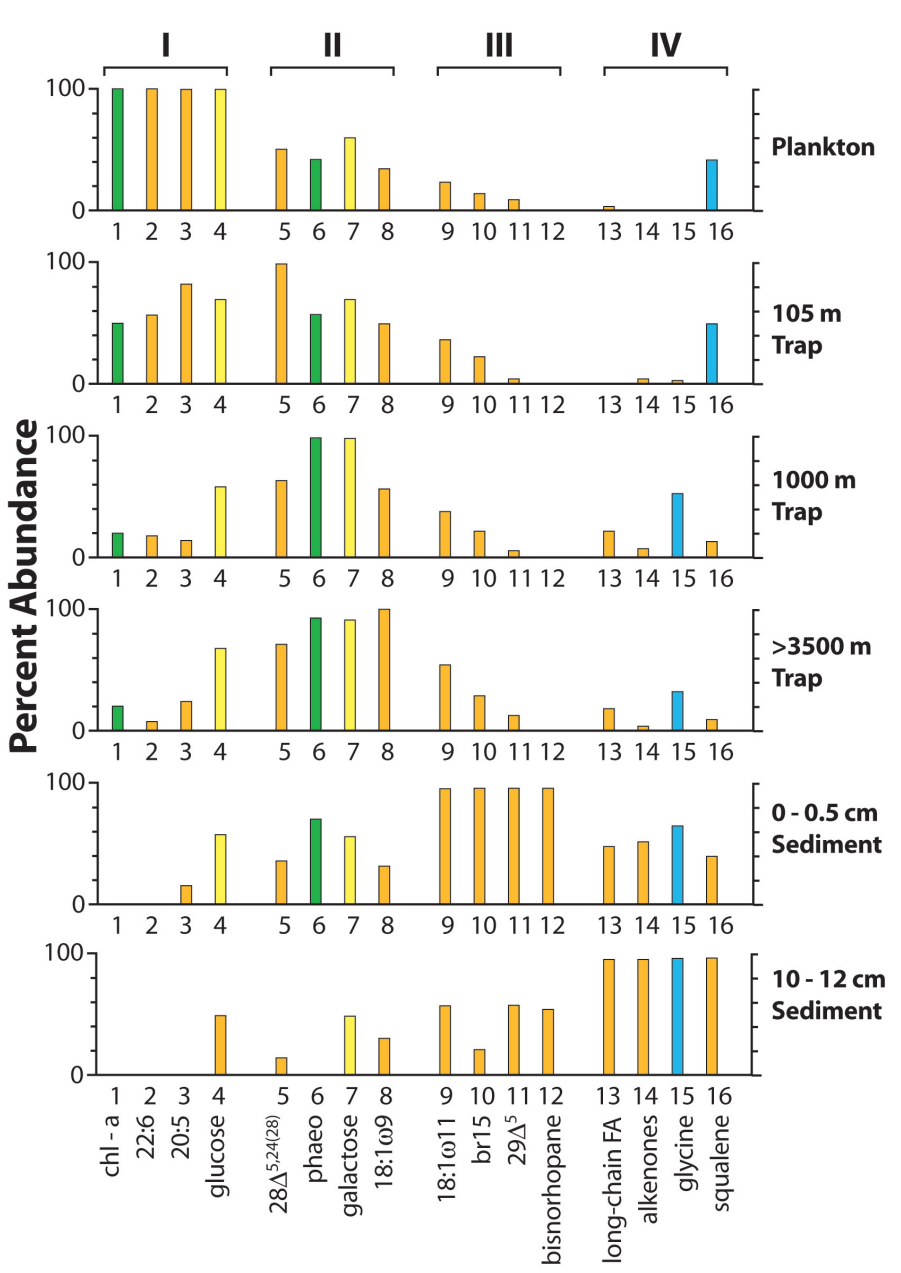

$\square$ amino acid $\quad \square$ sugar $\quad \square$ lipid $\quad \square$ pigment

Figure 4. Diagnostic biomarkers in plankton, trap material and surface sediments from the equatorial Pacific Ocean fall into four categories depending on their behavior. The bar sizes for each individual compound are normalized to the maximum relative abundance in one of the sample types. In Group I, compounds in the plankton are rapidly lost with depth. Group II compounds show maximum abundance at mid-depth because they are either resistant remains of plankton or are produced at mid-depth by zooplankton or bacterial heterotrophs. Group III biomarkers are likely produced by bacteria near the water-sediment interface. Group IV compounds are most abundant in subsurface sediments because they are produced there or because they are refractory remains of water column sources that have been selectively preserved. Adapted from Wakeham et al. (11).

enoids transported to the sea floor in sinking particles. Esterification of chlorins during zooplankton grazing may also be common; both steryl esters $(30,31)$ and carotenoid esters (32) of chlorins have been found in water column particles and sediments.

Microbial alteration reactions also affect organic matter composition, especially that of organic nitrogen compounds. Aspartic and glutamic acid, two commonly found amino acids in phytoplankton, decarboxylate to form non-protein amino acids that are not commonly found in phytoplankton and zooplankton. Ratios of protein to non-protein amino acids have been used as indicators of bacterial activity in sinking particles of several oceanic areas (5). These ratios can increase with depth in both water column particles and in sediments as bacteria degrade the original compounds. Another non-protein amino acid, ornithine, is a decomposition product of the protein amino acid arginine. Particulate ornithine fluxes increase with depth in the strong oxygen minimum off the coast of Mexico $(3,5)$. Recently, Dauwe and Middelburg (33) and Dauwe et al. (34) developed a degradation index that provides a statistical basis for quantifying the extent of organic matter degradation based on amino acid composition. Their work has inspired others to extend principal components analysis to include other organic diagenetic indicators $(35,36)$. In addition to consuming plankton-derived organic matter, bacteria colonizing a particle can synthesize new biomass either from organic matter within the particle or by consuming DOC. Bacterial biomarkers such as muramic acid have been used to quantify bacterial biomass in particulate matter and sediments (37, 38 ). Microbes can also be detected directly via nucleic acid stains such as DAPI; cell count data can then be used to estimate microbial biomass.

Rapid developments in molecular biology over the past few years (reviewed in 39) have provided a wide range of methods for accessing one of the 'ultimate' biomarkers, the 16s rRNA gene. This gene, conserved across all forms of life, varies slightly among species, providing an unambiguous fingerprint for specific members of prokaryotes and eukaryotes alike (40). Detection of 16s rRNA can be accomplished through extraction and PCR (polymerase chain reaction)based amplification of rDNA (41), or by applying FISH (fluorescent in situ hybridization) to directly stain rRNA in fixed cells using fluorescent probes that are complementary to specific regions of rRNA $(42,43)$. Extraction, PCR amplification, chromatographic separation, and sequencing of $16 \mathrm{~s}$ rRNA genes have provided insight into the vast diversity of microbes present in seawater, on particles, and in sediments. Direct comparisons of community response to specific environmental conditions or experimental manipulations can be made via TRFLP (terminal restriction fragment length polymorphism) or DGGE (denaturing gradient gel electrophoresis) $(44,45)$, while FISH staining provides the means of directly detecting subgroups of organisms in a specific sample. Depending on the type of PCR primer or FISH probe used, the information gained can be at the broad division or at the single species level. Current work is also focused on detection and quantification of specific functional genes in order to understand organism-process links (46). Genomic approaches (construction and analysis of clone libraries) are also being used to indicate the functional capabilities of uncultured organisms (47). These approaches can provide information about "who is there", and begin to suggest the types of processes in which they may be involved.

Use of multiple organic compounds as indicators of relative diagenetic reactivity can provide a sensitive and consistent means of comparing changes in the molecular "quality" of organic matter in aquatic environments. In the sea surface-to-sediment study mentioned earlier, Wakeham et al. (11) used a combination of 16 lipid, amino acid, pigment or carbohydrate compounds or groups of compounds to divide organic matter collected in the water column and sediment of the equatorial Pacific into four clearly-defined diagenetic classes that could be traced from sea surface to sediment (Fig. 4). For example, chlorophyll- $a$ and $\mathrm{C}_{20}$ and $\mathrm{C}_{22}$ polyunsaturated fatty acids were diagnostic of plankton in surface waters and were rapidly lost from particles in the euphotic zone. Zooplankton contributions of pheophorbide and oleic acid appeared deeper in the water column. Several organic compounds specific to bacteria such as muramic acid, cisvaccenic acid and iso and anteiso-15:0 fatty acids, served as source indicators of the presence of microbes or their products in particulate matter. They became important in deep-water particles and surface sediments. High-molecular-weight straight-chain fatty acids, fatty alcohols and al- 
kanes that are resistant to microbial alteration became more abundant in subsurface sediments. Changes in the molecular "quality" of particulate matter down the water column were accompanied by a substantial decrease in the amount of organic carbon that could be easily identified at the molecular level.

\section{WHAT IS THE "UNCHARACTERIZED” MATERIAL?}

What can cause the large increase in uncharacterized material in the mesopelagic zone? First it is important to remember that complete characterization is seldom possible and was not accomplished in the equatorial Pacific study, where over 150 individual compounds were identified (11). Wakeham et al. defined characterized material as that which could be chromatographically determined as hydrolyzable amino acids, neutral sugars, solvent-extractable lipids, and chlorophyll and its immediate degradation products. There are in fact many compounds outside this analytical "window". Application of other analytical tools may have identified many more compounds, e.g. amino sugars, nucleic acids, lectins, uronic acids (48) and other acidic sugars, glycosylated or otherwise abiotically-modified proteins (49), adsorbed quinones, etc. The proportion of total carbon contributed by these other compounds is unknown simply because they have not been measured. However, it is unlikely that their contributions increased as dramatically with depth as did the uncharacterized fraction of organic matter, though possible if they are very resistant to degradation (see later discussion). Furthermore, the macromolecular nature of compounds was not determined in the Wakeham et al. study since a hydrolysis step was usually used. In that study, molecular-level characterization provided no information on the manner in which individually identified compounds are linked together. Such information about macromolecular structure, however, is likely critical to considerations of bioavailability and susceptibility to degradation. Since remineralization of macromolecules requires hydrolysis (in the digestive apparatus of eukaryotic organisms, or by extracellular enzymes prior to transport into microbial cells), the manner in which individual building blocks such as amino acids, simple sugars, and lipids are linked as complex structures is a central issue. Macromolecular structural information is rare at the present time: methods used to analyze intact samples (solid state NMR, for example) do not have the resolution required to provide this information, while most other analytical approaches require chemical or thermal decomposition of complex samples - and therefore loss of this information - to analyze the residual monomers.

"Analytically uncharacterized" is synonymous with neither "biologically available" nor "biologically unavailable" carbon. Although it may be tempting to equate "analytically uncharacterized" and "biologically unavailable", ample evidence suggests that microbes do not do so. Identifiable amino acids and carbohydrates persist at depth in sediments of considerable age (50); the specific factors that render them resistant to microbial remineralization remain to be determined. Conversely, uncharacterized carbon is not necessarily biologically recalcitrant. Even though sediment can contain a large proportion of uncharacterized carbon $(>80 \%)$, absolute concentrations of the uncharacterized fraction continue to decrease in the sediment column (11), and this carbon can still support comparatively high rates of microbial metabolism (51). Whatever its molecular character, most of the organic matter that reaches the seafloor appears to be biologically available to benthic organisms, even though it may be analytically uncharacterized.

A further point to consider is that molecular biological surveys have shown that microbial community composition can vary greatly with location as well as in response to environmental conditions $(52,53)$. Although efforts to link functional to phylogenetic diversity are still in their early stages, it is reasonable to suppose that the tools that these diverse microbial communities have to access macromolecular substrates may differ significantly. A survey of extracellular enzyme activities in seawater microbial communities ranging from $39^{\circ} \mathrm{S}$ to $79^{\circ} \mathrm{N}$ showed that patterns of enzyme activities varied greatly; several polysaccharides that remained unhydrolyzed in seawater from high-latitude locations were rapidly hydrolyzed in the Gulf of Mexico (54). Comparisons of seawater and sedimentary microbial communities have also demonstrated that some soluble polysaccharides remain unhydrolyzed in seawater, although they are readily hydrolyzed in surface sediments from the same location $(54 \mathrm{a}, 55)$.

Below we discuss possible sources of uncharacterized material in addition to the "unmeasured" category discussed above. These include direct sources of uncharacterized material (microbes, black carbon, biomacromolecules) and processes that might lead to their production (selective degradation, organic-mineral interactions, aggregation).

\section{Microbial Biomass or Microbial Products}

Many of the uncharacterized compounds in the "unmeasured" fraction mentioned above are found in microbial biomass or microbial products (Fig. 2). Lee (56) suggested that the accumulation of bacterial biomass could be responsible for much of the organic carbon preserved in sediments. Biomarker studies also indicate that bacterial biomass makes a significant contribution to sedimentary carbon (57), but studies focusing on bacterial biomarkers in particulate matter are limited in number. It is unlikely that bacterial biomass contributes a major fraction of the carbon in sinking particles (5), where the POC can be actively recycled by the water column grazing community. Bacterial counts on sediment trap particles suggest that bacterial concentrations on particles are similar to concentrations of free-living particles in seawater. Ducklow et al. (58) report average concentrations of $1150(10)^{9}$ cells $\mathrm{g}^{-1}$ POC in trap material, half of which are attached. Thus, if we use $12.4 \mathrm{fg} \mathrm{C}$ per bacterial cell (59), viable bacterial biomass (1-2\% of total POC) does not appear to be large enough to account for a substantial fraction of the $\mathrm{C}$ in sinking particles, although bacteria contribute somewhat more $(\sim 4 \%)$ to sedimentary carbon $(56)$.

The contribution of microbial products to POC is not at all well known. Bacteria produce a wide range of extracellular polymeric substances (EPS) to form multifunctional capsules, sheaths, or gel-like matrices (60). EPS are composed of polysaccharides, proteins, nucleic acids and lipids. Much of the $\mathrm{C}$ in these bacterial products may not be "molecularly-characterized" by the relatively simple chromatographic scheme used in previous studies. As a simple example, the amino sugars glucosamine and galactosamine were not included in the characterization. Benner and Kaiser (61) estimated that these two amino sugars make up $1-2 \%$ of the carbon in suspended POC. Hydroxy fatty acids of bacterial origin constitute $<1 \%$ of $\mathrm{OC}$ in particulate matter (62).

The ${ }^{13} \mathrm{C}$-NMR results of Hedges et al. (15) suggested that sinking particle organic compositions were consistent with the presence of intrinsically resistant biomacromolecules 
with a bulk chemical composition similar to that of plankton being selectively preserved as particulate organic matter sinks. Hedges et al. suggested that peptidoglycan, a common macromolecule in bacterial cell walls, might fit this description since downward increases of glycine and total carbohydrate found in sinking particle samples were consistent with a growing peptidoglycan content. Benner and Kaiser (61) measured concentrations of muramic acid, a compound found only in bacterial peptidoglycan. They found it to be as concentrated in POM as in bacteria. But bacteria were not found in high enough numbers to account for all the peptidoglycan in their samples, so they hypothesized that much of the peptidolgycan in POM is detrital. Muramic acid was not included in the Wakeham et al. (11) inventory. Nor were uronic acid and other acidic carbohydrates that are common in bacterial exudates (63). Uhlinger and White (64) found that uronic acids increase with time in microbial exopolysaccharides, which eventually accumulate to be as much carbon as in the original microbial cell.

Transparent exopolymer particles (TEP) are another set of biomacromolecules common in seawater (65) and thought to be produced by both bacteria and algae. TEP plays a major role in flocculation in the ocean (66), and is thus likely to be present in sinking particles. Only about half of the carbohydrates in TEP are neutral sugars (67), the type measured by Wakeham et al. (11). The remaining carbohydrate fraction was unidentified, but thought to contain sugar alcohols and monosaccharide degradation products. Acidic sugars such as uronic acids are not a major fraction of TEP, but sulfated deoxysugar-containing polysaccharides are likely components (68). Thus, some of the uncharacterized fraction is probably not-yet-identified compounds of bacterial origin that are produced on particles. Their increasing proportion with depth, rather than the presence of inherently resistant compounds, would then be responsible for an increase in uncharacterized material with depth.

\section{Black Carbon}

Another type of organic matter that may contribute to uncharacterized $\mathrm{C}$ is black carbon (Fig. 2). Black carbon (BC, including soot and charcoal) is a highly condensed, carbonrich product of incomplete combustion of biomass and fossil fuels; graphitized BC (GBC) may arise from weathering of ancient sediments. $\mathrm{BC}$ is now recognized to play a significant role in the global carbon cycle, and although purely terrigenous in origin is apparently also prevalent in the marine environment (reviewed in Schmidt and Noack (69)). Because analyses of BC are highly operational (70-72), reported contributions of $\mathrm{BC}$ to marine $\mathrm{OC}$ are highly variable, perhaps up to $30 \%$ of OC $(73,74)$. BC in marine POM has not been measured to date, but Deuser et al. (75) found fly-ash particles in sediment trap material collected in the Sargasso Sea. $\mathrm{BC}$ is highly surface-active and hence readily sorbs organic substances, so that many forms of marine organic matter could readily become associated with $\mathrm{BC}$-rich particles. As $\mathrm{BC}$ is already highly oxidized, it might be highly resistant to degradation, although evidence for its degradation is mixed (74); if highly refractory, then BC might offer considerable protection to any sorbed organic substances. In a comparison of contributions to sedimentary OC by hexosamines, amino acids, and carbohydrates, $\mathrm{BC}$ was found to constitute $15-40 \%$ of the unidentified OC (which in turn represented $60-80 \%$ of total OC) (74). It is clear that BC might be a very important and at present understudied fraction of marine OC, and its contribution needs to be better evaluated.

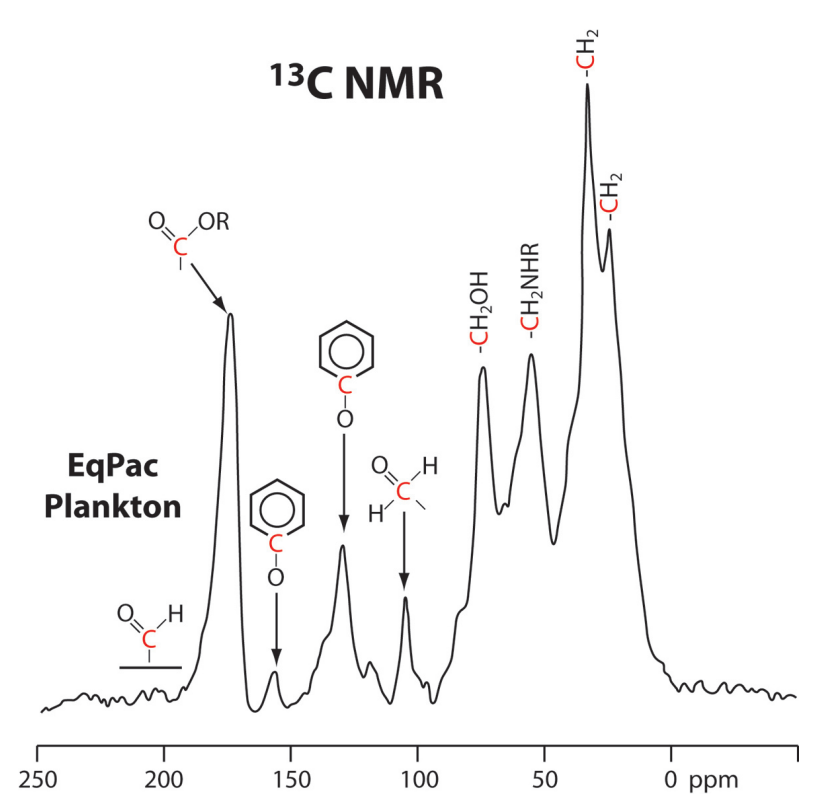

Figure $5 .{ }^{13} \mathrm{C}-\mathrm{NMR}$ spectrum of marine particulate material showing the major organic functional groups that are assigned to specific resonances.

\section{Geomacromolecule Formation/Selective Preservation}

Labile intermediates released during microbial degradation of biomacromolecules (e.g. polysaccharides, lignins and proteins) may spontaneously recombine to form chemically complex "geopolymers" (76, 77) (Fig. 2). These geomacromolecules may be structurally too complex to analyze chemically, and may increase preferentially with depth if they do not degrade enzymatically. Alternatively, some biomacromolecules may be intrinsically resistant to biodegradation and thus may also be selectively preserved. Numerous hydrolysis-resistant biomacromolecules have been identified in terrestrial and marine plants and bacteria, as well as in sedimentary environments (77). However, both these mechanisms should result in pronounced changes in organic matter composition as particles are degraded in the water column.

The study of plankton and sediment trap material from the equatorial Pacific and Arabian Sea by Hedges et al. (15) suggested that major biochemical compositions obtained by modeling solid-state ${ }^{13} \mathrm{C}$-NMR spectra (e.g. Fig. 5) were similar to those directly measured by chromatographic analysis of these same samples. This compositional similarity, while surprising, was true both for shallow samples where $80 \%$ of the organic carbon was chromatographically characterized, and for deep trap samples where only $20 \%$ of the POC was characterized. There was no evidence for the increase with depth in alkyl carbon that would be expected from selective preservation of aliphatic algaenan-like biopolymers, or for the increase of unsaturated carbon expected from humification. Hedges et al. (15) concluded that most of the lost organic matter was recycled in the water column with little or no chemical selectivity. Although these results provide strong evidence against substantial selective degradation and humification as sinking ocean particles are extensively remineralized, other mechanisms might also lead to the observed biochemical uniformity. For example, stereochemical changes or crosslinking of proteins and polysaccharides in plankton might increase their resistance to biodegradation 
and yet not be detectable by ${ }^{13} \mathrm{C}$ NMR. In addition, intrinsically resistant biomacromolecules with a bulk chemical composition similar to plankton might be selectively preserved as particulate organic matter sinks.

An unknown factor is the extent to which microbial communities vary spatially in their abilities to make use of specific structures as mentioned earlier, as well as to the extent to which they are reliant upon degradation of macromolecular compounds for their metabolism. If surface-water microbial communities have the ability to dismantle a wider variety of macromolecules than do deep-water communities, organic matter that initially escapes remineralization due to rapid sinking, encapsulation, aggregation, or surface-association, for example, may be enzymatically inaccessible for deep-water communities. One significant puzzle relates to planktonic Archaea, which are a large fraction of total prokaryotic biomass at depths in excess of $1000 \mathrm{~m}$ in the North Pacific gyre (78) and in Antarctic surface waters in the winter (79). Because none of these organisms has been isolated in culture, there is no specific information about their metabolism, although some Archaea may use bicarbonate (80). Analysis of lipid biomarkers from the Santa Barbara Basin supports the idea that in this environment, Archaea do not use surface-derived DOC or post-bomb $\mathrm{CO}_{2}$ to synthesize their cellular carbon (81). Perhaps particle composition in the ocean interior is in part the result of microbial indifference to the rain of material sinking through this region.

In support of the selective preservation hypothesis, more recent results using direct temperature-resolved mass spectrometry (DT-MS) of the same samples studied by Hedges et al. (15) suggest that a substantial proportion of the uncharacterized material is in fact dominated by recognizable biochemical signals (82). Although DT-MS analysis gives a picture intermediate between the earlier chromatographic (i.e. 11) and NMR (i.e. 15) scales of compositional resolution, it suggests that biogeochemical alterations indeed do occur within the water column but do not result in radical changes to the primary molecular structure of the bulk of the particulate organic matter. Minor et al. (82) conclude that neither extensive physicochemical nor biologically-mediated geopolymerization occur in the water column. Instead, there appears to be selective removal and editing of the surface-derived organic matter leading to selective preservation of a portion of this organic matter in deep water and sediments.

On the other hand and in direct contrast to the chromatographic, ${ }^{13} \mathrm{C}-\mathrm{NMR}$ and DT-MS results, Hwang and Druffel (83) used isotopic evidence to suggest that the uncharacterized material is "lipid-like" material that has selectively accumulated. They measured stable and radiocarbon isotopes of different chemically-isolated fractions of sinking POC from sediment traps from the California margin. An acid-insoluble fraction was used as a proxy for the uncharacterized fraction, and was found to have the same isotopic signature as the lipid fraction obtained by conventional solvent extraction, but a different isotopic signature from the amino acids and carbohydrates. This exciting work is consistent with the hypothesis that the uncharacterized material is formed by selective preservation of algaenan-type structures $(76,84)$. Future isotopic work in areas not so dominated by terrestrial sources of old carbon (petroleum or weathered ancient rocks) will show whether a "lipid-like" isotopic signature of the uncharacterized fraction is general in the ocean.

\section{Mineral/Organic Matrix Interactions}

Compositional similarities of the major biochemicals in POC over the entire water column are more consistent with a hypothesis that physical protection of organic matter by an associated mineral matrix is more important than selective preservation based solely on molecular factors as described above (15). Several mechanisms could account for physical protection of organic matter by minerals. Inorganic matter makes up most of the total mass of sinking particles. If organic matter and a mineral matrix are intimately associated with each other, this association may afford physical protection to the organic fraction. Adsorption of organic compounds onto a mineral matrix can protect them from microbial degradation (85), perhaps by promoting intermolecular interactions between adjacent molecules adsorbed to a surface (86). Adsorption of DOC onto a mineral matrix could significantly increase the proportion of uncharacterized organic compounds on particles since most of DOC is itself uncharacterized (87). In this respect, it would be interesting to determine whether diagnostic bacterial components of DOC (e.g. peptidoglycan-derived D-amino acids (88) or hydroxy acids (89)) might be present in the uncharacterized fraction of POC. However, it is not clear why this process would occur more in the mesopelagic than any other ocean depth.

Mayer (90) confirmed earlier studies showing that organic matter coats mineral particles in concentrations equivalent to a "monolayer" and postulated that adsorption of organic matter into mesopores physically removes it from the action of hydrolyzing enzymes, which cannot function within the tiny pores. He hypothesized that this mechanism is responsible for the almost universal correlation between organic carbon content and mineral grain size observed in marine sediments. Likewise, some fraction of the organic matter might be protected in mesopores of particles sinking through the water column. Recently, the mesopore hypothesis has been modified to consider discrete organic aggregates on mineral surfaces (91-93). Organic matter acts as a "glue" to hold particles together, and the organic glue may be protected from decomposition by its location in these intergranular areas $(94,95)$. In either case, there appears to be a threshold below which sorbed organic matter cannot be attacked by exoenzymes. On the other hand, a surprisingly high proportion of organic matter sorbed to particles is reversibly bound. Experiments have shown that once desorbed, this organic matter is remarkably susceptible to microbial degradation (96, 97). In addition, there are clear compositional variations as a function of particle size $(98,99)$ which may affect OC behavior. Hedges and Keil (50) developed the mineral-protection hypothesis further by suggesting that organic matter in association with mineral material beyond that equivalent to a mono-layer coating might be due to its isolation from oxygen. Subsequently, Hedges et al. (100) showed that the nature of organic matter in surface sediments off the coast of Washington State, USA, was highly dependent on exposure time to oxygen. It is intriguing to extrapolate this observation to water column particles, for which suboxic or anoxic conditions might exist within the particles themselves.

It is also possible that refractory macromolecular organic or inorganic matrices may protect intrinsically labile organic substances. Knicker and co-workers $(101,102)$ suggested that proteins could be encapsulated within refractory macromolecular organic matrices and thus be preserved. This encapsulation hypothesis is supported by experimental observations by Nguyen et al. (103) that protein can be pre- 
served during degradation of algaenan-rich algae. Resistant organic matrices may also protect otherwise labile lipids. For example, waxy epicuticular coatings common to land plants apparently protect higher plant alkanes, fatty acids, and fatty alcohols from degradation. Thus, terrestrial biomarkers may be relatively abundant in abyssal sediments even though they are minor components of the particles produced in the overlying waters (104). The behavior of marine-derived compounds suggests that they lack a protective matrix and thus are subject to preferential degradation in the water column.

Some organic matter is incorporated into silicate and carbonate tests during biological deposition of these minerals (105). This organic material is entombed within the mineral matrix and will not be exposed to hydrolyzing enzymes until it is released when the mineral phase dissolves. In particular, preservation of several amino acids and sugars occurs in both siliceous and carbonate tests. Diatom cell walls, for example, contain a protein-silica complex (106), whose preservation is thought to account for the increase in glycine and serine commonly observed with depth in marine particles $(3,107)$. Carbonates are often enriched in acidic amino acids, which are thought to participate in the carbonate precipitation mechanism (105). These acidic amino acids and glycine are the dominant compounds found in deep equatorial Pacific sediment traps and sediment (12) where they appear to be protected until they are exposed following dissolution of the associated mineral phase. The mechanism of association of organic matter to mineral grains is not well understood and is probably multi-faceted. Simple adsorption undoubtedly plays a major role. If the mineral is terrestrially-derived, adsorption could occur before deposition in the ocean; the organic coating could remain with the particle when the mineral grain enters the water, could be replaced by marine DOC, or further adsorption of marine DOC could occur. Work by Keil et al. (108) and Hedges and Keil (109) demonstrate this process. Berner (110) suggested that benthic animals may coat fine-grained minerals as they pass through animal guts; this process could also occur in the water column as particles pass through zooplankton guts. And, as mentioned above, organic matter could be contained within the inorganic skeletal matrices of organisms. Ingalls et al. (36) found that amino acids bound within the opal fraction made up $3-4 \%$ of the amino acids in sinking particles; this proportion increased with depth, and reached $60 \%$ in sediments of the silica-rich Southern Ocean.

The suggestion that minerals both preserve associated organic matter and provide ballast that allows particles to sink has led to a new conceptual model about factors that control organic matter fluxes and composition in the ocean (16). Typical mixes of organic carbon compounds that comprise marine organic matter have densities close to that of seawater, while the density of typical inorganic mineral ballast is about 2-2.5 times that of seawater. Since sinking velocities are proportional to the excess in density over that of the fluid through which particles sink, a particle that is half organic matter and half inorganic ballast will sink many times faster than a particle of comparable size composed totally of organic matter. Wind-blown (terrestrial) dust particles, opaline silica (produced by diatoms and radiolarians), and calcium carbonate (produced by coccolithophorids and foraminifera) are the major types of mineral ballast in the world ocean (9, 10). Dust that does not dissolve appreciably with depth in the ocean, and therefore does not expose its associated organic matter to degradative enzymes, will carry its protected organic matter efficiently during transit through most of the water column to the sea floor. In contrast, organic matter external or internal to opal and carbonate tests will be subject to decomposition as the biomineral begins to dissolve. The mineral phase with which organic material is associated may therefore provide a strong control on organic carbon flux in two ways: through mineral-specific differences in the amount of organic carbon that can be protected internally per unit ballast mineral, and through differential exposure of internal organic matter resulting from differential dissolution of the ballast minerals themselves. Considering mineral ballast and protection, a quantitative description of POC remineralization must account both for POC that is "protected" by its association with ballast and for POC that is "unprotected" from degradation. Both types of POC are assumed to be associated with the same sinking aggregates (flocs and/or fecal pellets); the same ballast would then provide the excess density needed for both types of carbon to sink. Only further research on organic-inorganic associations will allow progress in making quantitative and predictive models of organic matter flux that are useful over broad regions of the ocean and over seasonal and interannual time scales. The concept of physical protection, whether by sorption, encapsulation, or other mechanisms, provides a plausible explanation for the presence of amino acids, carbohydrates, or other identifiable structures as components of persistent organic matter. The question as to why such materials should be identifiable with techniques such as solid-state NMR and DT-MS, yet resist hydrolysis and chromatographic identification, is still unanswered.

\section{Aggregation-Disaggregation}

Many of the processes mentioned above are likely sources of uncharacterized material, but why is the major transition from characterized to uncharacterized observed in the mesopelagic zone? Aggregation and disaggregation processes that occur especially widely in the mesopelagic zone may result in incorporation of older and more degraded (and less easily characterized) suspended material into large sinking particles, such as marine snow (Fig. 2). If we consider the hypothesis of Hill (111), large particles sinking through the water column at high rates fragment because of high shear stresses until they reach a size at which their sinking rate slows and shear stresses diminish. As these now smaller particles sink slowly, they collide with other smaller particles, and can reaggregate into larger particles again. This aggregation-disaggregation process results in the constant rain of material of a similar size all the way to the sea floor, and in sinking and suspended particles that have exchanged material with each other. Aspects of the effects of this continual aggregation-disaggregation on the chemical composition of particulate matter have been examined in the past (112), but recently, Sheridan et al. (35) used principal components analysis of pigment, lipid and amino acid compositions to show that suspended particles in surface waters (0-200 m) are dominated by fresh organic material and are similar in composition to surface ocean phytoplankton. Suspended particles are less degraded than particles sinking out of the euphotic zone at $105 \mathrm{~m}$. However, the organic composition of midwater suspended particles (200-850 m) showed that these particles are of a similar "freshness" to sinking particles throughout the mesopelagic zone, likely due to this exchange between sinking and suspended particles at depth. These depth variations in phytoplankton, zooplankton, and bacterial biomarkers support the idea that surface suspended particles are composed primarily of labile phytoplankton 
material, whereas midwater particles are composed of phytodetritus diluted with zooplankton and microbial source material at depth. These new observations provide conclusive evidence for the complex dynamics between large, fast-sinking and small, slow-sinking particles that could only be hinted at in the past. Because mesopelagic depths are characterized by such dynamic physical and biological processes, the most probable mechanism for the increase in uncharacterized material in this zone likely includes physical (aggregation-disaggregation) and biological (selective degradation) components.

\section{FINAL THOUGHTS}

It is interesting to compare decomposition of marine particulate organic matter with that in soils and sewage. Baldock and Skjemsted (113) review evidence for soil organic matter decomposition that suggests the critical role of mineral matrices in protecting organic matter. They suggest that soil organic matter decomposition is highly complex because of the large range in size and source of both the minerals and the organic matter present in soils. Larger particles retaining intact biologically-produced compounds are influenced most by the soil architecture, i.e. the degree of encapsulation, aggregate stability and pore size. For smaller particle sizes in the soils, Baldock and Skjemstad suggest that adsorption onto mineral surfaces and the types of soil minerals and cations present become dominant influences on decomposition rates. In soils, mineral protection is only temporary, slowing decomposition relative to unprotected organic matter. Long residence times will also increase the quantitative importance of selective preservation of biomacromolecules. Based on knowledge of soil mechanisms, it will be interesting to further explore the interaction between marine organic matter and minerals in producing labile but uncharacterized $\mathrm{OM}$ in the ocean.

Dignac and others $(114,115)$ describe the production of uncharacterized organic matter during the treatment of wastewater with activated sludge; as in marine systems, uncharacterized material in wastewaters accounted for a substantial fraction of the total carbon present in degraded material. Dignac et al. suggested that the uncharacterized material resulted from the presence of organic compounds not characterized by molecular analysis, the presence of salts that interfere with hydrolysis, or the presence of compounds refractory to chemical hydrolysis. But they thought it most likely that refractory OM was formed by complex rearrangements of simple biochemicals during the activated sludge treatment. More than $80 \%$ of the organic matter is decomposed during treatment, similar to the percentage of particulate organic matter produced in the euphotic zone of the ocean that is degraded in the water column (114). However, marine organic matter is produced in close association with biominerals, and once produced, it can be consumed by animals as well as microbes. Another interesting difference between oceanic and wastewater environments is that the uncharacterized material produced during wastewater treatment appears to be refractory, while in the ocean much of the material sinking in the water column can be further decomposed once it reaches the sea floor. Although wastewater and sludge are rich in organic carbon, a substantial portion of the mass is still inorganic as shown by ash contents $>$ $30 \%$ (115). Thus, it may be of value to explore the effects of inorganic constituents in wastewater and sludge remineralization processes.
Further comparison of organic matter decomposition in marine particles with that in soils and wastewater may prove extremely useful in distinguishing between important decomposition mechanisms. These three diverse environments represent a continuum in mineral and organic matter concentrations and in biological processing times, with soils having high mineral content and long reaction times over which decomposition occurs, and wastewater having high concentrations of organic matter but lower mineral contents and shorter processing times. Marine particles lie between these extremes. Extended periods of time and high organic concentrations will result in chemical reactions that lead to production of refractory compounds. Short processing times, higher mineral content, and lower chemical concentrations will result in more preservation.

\section{References and Notes}

1. Martin, J.W., Knauer, G.A., Karl, D.M. and Broenkow, W.W. 1987. VERTEX: carbon cycling in the northeast Pacific. Deep-Sea Res. 34, 267-285.

2. Barber R.T., Sanderson, M.P., Lindley, S.T., Chai, F., Newton, J., Trees, C.C., Foley, D.G. and Chavez, F.P. 1996. Primary productivity and its regulation in the equatorial Pacific during and following the 1991-92 El Niño. Deep-Sea Res. II 43, 963-969.

3. Lee, C. and Cronin, C. 1984. Particulate amino acids in the sea: Effects of primary productivity and biological decomposition. J. Mar. Res. 42, 1075-1097.

4. Ittekkot, V., Deuser, W.G. and Degens, E.T. 1984. Seasonality in the fluxes of sugars, amino acids, and amino sugars to the deep ocean: Sargasso Sea. DeepSea Res. 31, 1057-1069.

5. Wakeham, S.G. and Lee, C. 1993. Production, transport, and alteration of particulate organic matter in the marine water column. In: Organic Geochemistry Engel, M.H. and Macko, S.A. (eds). Plenum Press, pp. 145-169.

6. Karl, D.M., Knauer, G.A., Martin, J.H. and Ward, B.B. 1984. Bacterial chemolithotropy in the ocean is associated with sinking particles. Nature 309, 54-56.

7. Taylor, G.T., Scranton, M.I., Iabichella, M., Ho, T.-Y.,Thunell, R.C. and Varela, R. 2001. Chemoautotrophy in the redox transition zone of the Cariaco Basin: A significant source of midwater organic carbon production. Limnol. Oceanogr. $46,148-163$

8. Deuser, W.G. 1986. Seasonal and interannual variations in deep-water particle fluxes in the Sargasso Sea and their relation to surface hydrography. Deep-Sea Res. 33, 225-246.

9. Honjo, S., Dymond, J., Collier, R. and Manganini, S.J. 1995. Export production of particles to the interior of the equatorial Pacific Ocean during the $1992 \mathrm{EqPac}$ experiment. Deep-Sea Res. II 42, 831-870.

10. Honjo, S., Dymond, J., Prell, W. and Ittekkot, V. 1999. Monsoon-controlled export fluxes to the interior of the Arabian Sea. Deep-Sea Res. II 46, 1859-1902.

11. Wakeham, S.G., Lee, C., Hedges, J.I., Hernes, P.J. and Peterson, M. 1997. Molecular indicators of diagenetic status in marine organic matter. Geochim. Cosmochim. Acta 61, 5363-5369.

12. Lee, C., Wakeham, S.G. and Hedges, J.I. 2000. Composition and flux of particulate amino acids and chloropigments in equatorial Pacific seawater and sediments. Deep-Sea Res. I 47, 1535-1568

13. Suess, E. 1980. Particulate organic carbon flux in the oceans - surface productivity and oxygen utilization. Nature 288, 260-263.

14. Lee, C., Murray, D.W., Barber, R.T., Buesseler, K.O., Dymond, J., Hedges, J.I. Honjo, S., Manganini, S.J., Marra, J., Moser, C., Peterson, M.L., Prell W.L. an Wakeham, S.G. 1998. Particulate organic carbon fluxes: Results from the U.S. JGOFS Arabian Sea Process Study. Deep-Sea Res. II 45, 2489-2501.

15. Hedges, J.I., Baldock, J.A., Gélinas, Y., Lee, C., Peterson, M. and Wakeham, S.G. 2001. Evidence for non-selective preservation of organic matter in sinking marine particles. Nature 409,801-804.

16. Armstrong, R.A., Lee, C., Hedges, J.I., Honjo, S. and Wakeham, S.G. 2002. A new, mechanistic model organic carbon fluxes in the ocean based on the quantinew, mechanistic model organic carbon fluxes in the ocean based on the quanti-
tative association of POC with ballast minerals. Deep-Sea Res. II 49, 219-236.

17. Hedges, J.I., Eglinton, G., Hatcher, P.G., Kirchman, D.L., Arnosti, C., Derenne, S., Evershed, R. P., Kögel-Knabner, I., de Leeuw, J. W., Littke, R., Michaelis, W. and Rullkötter, J. 2000. The molecularly-uncharacterized component of nonliving organic matter in natural environments. Org. Geochem. 31, 945-958.

18. Verdugo, P., Alldredge, A.L., Azam, F., Kirchman, D.L., Passow, U. and Santschi, P.H. 2004. The oceanic gel phase: A bridge in the DOM-POM continuum. Mar. Chem. (In press).

19. McCave, I.N. 1975. Vertical flux of particles in the ocean. Deep-Sea Res. 22, 491-502.

20. McCave, I.N. 1984. Size spectra and aggregation of suspended particles in the ocean. . Deep-Sea Res. 31,329-351.

21. Lee, C. and Wakeham, S.G. 1989. Organic matter in sea-water: biogeochemical processes. In: Chemical Oceanography. Riley, J.P. (ed.). Vol. 9. Academic Press, pp. 1-51

22. Volkman, J.K., Barrett, S.M., Blackburn, S.I., Mansour, M.P., Sikes, E.L. and Gelin, F. 1998. Microalgal biomarkers, a review of recent research developments. Org. Geochem. 29, 1163-1179.

23. Cowie, G.L. Hedges, J.I and Calvert, S.E. 1992. Sources and relative reactivities of amino acids, neutral sugars, and lignin in an intermittently anoxic marine environment. Geochim Cosmochim. Acta 56, 1963-1978.

24. Hernes, P.J., Hedges, J.I., Peterson, M.L., Wakeham, S.G. and Lee, C. 1996 Neutral carbohydrate geochemistry of particulate matter in the central equatorial Pacific. Deep-Sea Res. II 43, 1181-1204. 
25. de Baar, H.J.W., Farrington, J.W. and Wakeham, S.G. 1983. Vertical flux of fatty acids in the North Atlantic Ocean. J. Mar. Res. 41, 19-41.

26. Prahl, F.G., Eglinton, G., Corner, E.D.S. and O'Hara, S.C.M. 1985. Faecal lipids released by fish feeding on zooplankton. J. Mar Biol. Assoc. U.K. 65, 547-560.

27. Harvey, J.R., Eglinton, G., O'Hara, S.C.M. and Corner, E.D.S. 1987. Biotransformation and assimilation of dietary lipids by Calanus feeding on a dinoflagellate. Geochim. Cosmochim. Acta 51,3031-3040.

28. Welschmeyer, N.A. and Lorenzen, C.J. 1985. Chlorophyll budgets: Zooplankton grazing and phytoplankton growth in a temperate fjord and the Central Pacific Gyres. Limnol. Oceanogr. 30, 1-21.

29. Repeta, D.J. and Gagosian, R.B. 1984. Transformation reactions and recycling of carotenoids and chlorins in the Peru upwelling region $\left(15^{\circ} \mathrm{S}, 75^{\circ} \mathrm{W}\right)$. Geochim. Cosmochim. Acta 48, 1265-1277.

30. King, L.L. and Repeta, D.J., 1991. Novel pyropheophorbide steryl esters in Black-Sea sediments, Geochim. Cosmochim. Acta 55, 2067-2074.

31. Prowse, W.G. and Maxwell, J.R. 1991. High-molecular-weight chlorins in a lacustrine shale. Org. Geochem. 17, 877-886 1991.

32. Goericke, R., Shankle, A. and Repeta, D.J. 1999. Novel carotenol chlorin esters in marine sediments and water column particulate matter. Geochim. Cosmochim. Acta 63, 2825-2834.

33. Dauwe, B. and Middelburg, J.J. 1998. Amino acids and hexosamines as indicators of organic matter degradation state in North Sea sediments. Limnol. Oceanogr. 43, 782-798

34. Dauwe, B., Middelburg, J.J., Herman, P.M.J. and Heip, C.H.R. 1999. Linking diagenetic alteration of amino acids and bulk organic matter reactivity. Limnol. Oceanogr. 44, 1809-1814.

35. Sheridan, C.C., Lee, C., Wakeham, S.G. and Bishop, J.K.B. 2002. Suspended particle organic composition and cycling in surface and midwaters of the equatorial Pacific Ocean. Deep-Sea Res. I 49, 1983-2008.

36. Ingalls, A.E., Lee, C., Wakeham, S.G. and Hedges, J.I. 2003. The role of biominerals in the sinking flux and preservation of amino acids in the Southern Ocean along $170^{\circ} \mathrm{W}$. Deep-Sea Res. II 50, 709-734.

37. King, J.D. and White, D.C. 1977. Muramic acid as a measure of microbial biomass in estuarine and marine samples. Appl. Environ. Microbiol. 33, 777-783.

38. Moriarty, D.J.W. 1977. Improved method using muramic acid to estimate biomass of bacteria in sediments. Oecologia 26, 317-323.

39. Head, I.M., Saunders, J.R. and Pickup, R.W. 1998. Microbial evolution, diversity, and ecology: A decade of ribosomal RNA analysis of uncultivated microorganisms. Microb. Ecol. 35, 1-21.

40. Hugenholz, P., Goebel, B.M. and Pace, N.R., 1998. Impact of culture-independent studies on the emerging phylogenetic view of bacterial diversity. J. Bact $180,4765-4774$

41. Giovannoni, S.J., Britschgi, T.B., Moyer, C.L. and Field, K.G. 1990. Genetic diversity in Sargasso Sea bacterioplankton. Nature 345, 60-63.

42. Amann, R. 2000. Who is out there? Microbial aspects of biodiversity. System. Appl. Microbiol. 23, 1-8.

43. Amann, R., Krumholz, L and Stahl, D.A. 1990. Fluorescent-oligonucleotide probing of whole cells for determinative, phylogenetic, and environmental studies in microbiology. J. Bacteriol. 172, 762-770.

44. Muyzer, G. 1999. DGGE/TGGE a method for identifying genes from natural ecosystems. Curr. Op. Microbiol. 2, 317-322.

45. Osborn, A.M., Moore, E.R.B. and Timmis, K.N. 2000. An evaluation of terminal-restriction fragment length polymorphism (T-RFLP) analysis for the study of microbial community structure and dynamics. Environ. Microbiol. 2, 39-50.

46. Hallam, S.J., Girguis, P.R., Preston, C.M., Richardson, P.M. and De Long, E.F. 2003. Identification of methyl coenzyme M reductase A ( $\mathrm{mcr} \mathrm{A})$ genes associated with methane-oxidizing Archaea. Appl. Environ. Microbiol. 69, 5483-5491.

47. Beja, O., Koonin, E.V., Aravind, L., Taylor, L.T., Seitz, H., Stein, J.L., Bensen, D.C., Feldman, R.A., Swanson, R.V. and DeLong, E.F. 2002. Comparative genomic analysis of archael genotypic variants in a single population and in two nomic analysis of archael genotypic variants in a single population
different oceanic provinces. Appl. Environ. Microbiol. 68, 335-345.

48. Bergamaschi, B.A., Walters, J.S. and Hedges, J.I. 1999. Distributions of uronic acids and O-methyl sugars in sinking and sedimentary particles in two coastal marine environents. Acta 63, 413-425.

49. Keil, R.G. and Kirchman, D.L. 1993. Dissolved combined amino acids: Chemical form and utilization by marine bacteria. Limnol. Oceanogr. 38, 1256-1270.

50. Hedges, J.I. and Keil, R.G. 1995. Sedimentary organic matter preservation: an assessment and speculative synthesis. Mar. Chem. 49, 81-115.

51. Arnosti, C. and Holmer, M. 2003. Carbon cycling in a continental margin sediment: Contrasts between organic matter characteristics and remineralization pathways. Est. Coast Shelf Sci. 58, 197-208.

52. Fandino, L.B., Riemann, L., Steward, G.F., Long, R.A. and Azam, F. 2001. Variations in bacterial community structure during a dinoflagellate bloom analyzed by DGGE and 16S rDNA sequencing. Aq. Microb. Ecol. 23, 119-130.

53. Pinhassi, J., Winding, A., Binnerup, S. J., Zweifel, U. L., Riemann, B. and Hagström. A. 2003. Spatial variability in bacterioplankton community composition at the Skagerrak-Kattegat front. Mar. Ecol. Prog. Ser. 255, 1-13.

54. Arnosti, C., Durkin, S. and Jeffrey, W.H. 2004. Patterns of extracellular enzyme activities among pelagic microbial communities: Implications for cycling of dissolvedorganic carbon. Aq. Microb. Ecol. (In press).

54a. Arnosti, C. 2000. Substrate specificity in polysaccharide hydrolysis: Contrasts between bottom water and sediments. Limnol. Oceanogr. 45, 1112-1119.

55. Arnosti, C. 2002. Extracellular enzymes and their role in DOM cycling. In Aquatic Ecosystems: Interactivity of Dissolved Organic Matter. Findley, S. and Sinsabaugh, R.S. (eds). Academic Press, pp. 315-342

56. Lee, C. 1992. Controls on organic carbon preservation: The use of stratified water bodies to compare intrinsic rates of decomposition in oxic and anoxic systems. Geochim. Cosmochim. Acta 56, 3323-3335.

57. Canuel, E.A. and Martens, C.S. 1996. Reactivity of recently deposited organic matter: degradation of lipid compounds near the sediment water interface. Geochim. Cosmochim. Acta 60, 1793-1806.

58. Ducklow, H.W., Hill, S.M. and Gardner, W.D. 1985. Bacterial growth and the decomposition of particulate organic carbon collected in sediment traps. Cont. Shelf Res. 4, 445-464.

59. Fukuda, R., Ogawa, H., Nagata, T. and Koike, I. 1998. Direct determination of carbon and nitrogen contents of natural bacterial assemblages in marine environments. Appl. Environ. Microbiol. 64, 3352-3358.

60. Allison, D.G. and Sutherland, I.W. 1987. The role of exopolysaccharides in adhesion of freshwater bacteria. J. Gen. Microbiol. 133, 1319-1327.

61. Benner, R. and Kaiser, K. 2003. Abundance of amino sugars and peptidoglycan in marine particulate and dissolved organic matter. Limnol. Oceanogr. 48, 118128
62. Wakeham, S.G. 1999. Monocarboxylic, dicarboxylic and hydroxy acids released by sequential treatments of suspended particles and sediments of the Black Sea. Org. Geochem. 30, 1059-1074.

63. Kennedy, A.F.D. and Sutherland, I.W. 1987. Analysis of bacterial exopolysaccharides. Biotechnol. Appl. Biochem. 9, 12-19.

64. Uhlinger, D.J. and White, D.C. 1983. Relationship between physiological status and formation of extracellular polysaccharide glycocalyx in Pseudomonas atlantica. Appl. Environ. Microb. 45, 64-70.

65. Alldredge, A.L., Passow, U. and Logan, B.E. 1993. The abundance and significance of a class of large, transparent organic particles in the ocean. Deep-Sea Res. I 40, 1131-1140

66. Passow, U., Logan, B.E. and Alldredge, A.L. 1994. The role of particulate carbohydrate exudates in the flocculation of diatom blooms. Deep-Sea Res. I 41, 335357.

67. Mopper, K., Zhou, J., Sri Ramana, K., Passow, U., Dam, H.G. and Drapeau, D.T. 1995. The role of surface-active carbohydrates in the flocculation of a diatom bloom in a mesocosm. Deep-Sea Res. II 42, 47-73.

68. Zhou, J., Mopper, K. and Passow, U. 1998. The role of surface-active carbohydrates in the formation of transparent exopolymer particles by bubble adsorption of seawater. Limnol. Oceanogr. 43, 1860-1871.

69. Schmidt, M.W. I. and Noack, A.G. 2000. Black carbon in soils and sediments: analysis, distribution, implications and current challenges. Global Biogeochem. Cycles 14, 777-793.

70. Gélinas, Y., Prentice, K.M., Baldock, J.A. and Hedges, J.I. 2001. An improved thermal oxidation method for the quantification of soot/graphitic black carbon in sediments and soils. Environ. Sci. Technol. 35, 3519-3525.

71. Schmidt, MW. Skjemstad, J.O, Czimczik, C. I Glaser, B Prentice, K.M Gélinas, Y. and Kuhlbusch, T.A.J. 2001. Comparative analysis of black carbon in soils. Global Biogeochem. Cycles 15, 163-176.

72. Gustafsson, Ö., Bucheli, T.D., Kukulska, A., Andersson, M., Largeau, C., Rouzaud, J.-N., Reddy, C.M. and Eglinton, T.I. 2001. Evaluation of a protocol for the quantification of black carbon in sediments. Global Biogeochem. Cycles 15, 881-890.

73. Masiello, C.A. and Druffel, E.R.M. 1998. Black carbon in deep sea sediments Science 280, 1911-1913.

74. Middleburg, J.J., Nieuwenhuize, J and van Breugel, P. 1999. Black carbon in marine sediments. Mar. Chem. 65, 245-252.

75. Deuser, W.G., Emeis, K., Ittekkot, V. and Degens, E.T. 1983. Fly-ash particles intercepted in the deep Sargasso Sea. Nature 305, 216-218

76. Tegelaar, E.W., de Leeuw, J.W., Derenne, S. and Largeau, C. 1989. A reappraisal of kerogen formation. Geochim. Cosmochim. Acta. 53, 3103-3106.

77. de Leeuw, J.W. and Largeau, C. 1993. A review of macromolecular organic compounds that comprise living organisms an their role in kerogen, coal, and petroleum formation. In: Organic Geochemistry. Engel, M.H. and Macko, S.A. (eds) Plenum Press, pp. 23-72.

78. Karner, M.B., DeLong. E. and Karl, D.M. 2001. Archaeal dominance in the mesopelagic zone of the Pacific Ocean. Nature 409, 507-510.

79. Murray, A.E. Preston, C.M., Massana, R., Taylor, L. T., Blakis, A., Wu, K. and DeLong, E. 1998. Seasonal and spatial variability of bacteria and archaeal assemblages in the coastal waters near Anvers Island, Antarctica. Appl. Environ. Microbiol. 64, 2585-2595.

80. Wuchter, C., Schouten, S., Boschker, H.T.S. and Sinninghe Damste, J.S. 2003 Bicarbonate uptake by marine Crenarchaeota. FEMS Microb. Lett. 219, 203 207.

81. Pearson, A., McNichol, A.P., Benitez-Nelson, B.C., Hayes, J.M. and Eglinton, T.I. 2001. Origins of lipid biomarkers in Santa Monica Basin surface sediment: A case study using compound-specific $\Delta^{14} \mathrm{C}$ analysis. Geochim. Cosmochim. Acta 65, 3123-3137.

82. Minor, E.C., Wakeham, S.G. and Lee, C. 2003. Changes in the molecular-level characteristics of sinking marine particles with water column depth. Geochim. Cosmochim. Acta 67, 4277-4288.

83. Hwang, J. and Druffel, E.R.M. 2003. Lipid-like material as the source of the uncharacterized organic carbon in the ocean? Science 299, 881-884.

84. Largeau, C. and de Leeuw, J.W. 1995. In: Advances in Microbial Ecology, Jones, J.G. (ed.). Plenum Press, N.Y., pp. 77-117.

85. Gordon, A.S. and Millero, F.J. 1985. Adsorption mediated decrease in the biodegradation rate of organic compounds. Microb. Ecol. 11, 289-298.

86. Collins, M.J., Bishop, A.N. and Farrimond, P. 1995. Sorption by mineral surfaces: Rebirth of the classical condensation pathway for kerogen formation? Geochim. Cosmochim. Acta 59, 2387-2391.

87. Benner, R.,2002. Chemical composition and reactivity. In: Biogeochemistry of Marine Dissolved Organic Matter. Hansell, D. and Carlson, C. (eds). Academic Press, New York, pp. 59-90

88. McCarthy, M.D., Hedges, J.I., and Benner, R., 1998. Major bacterial contribution to marine dissolved organic nitrogen. Science 281, 231-234.

89. Wakeham, S.G., Pease, T.K. and Benner, R. 2003. Hydroxy fatty acids in marine dissolved organic matter as indicators of bacterial membrane material. Org. Geochem. 34, 857-868.

90. Mayer, L.M. 1994. Surface area control of organic carbon accumulation in continental shelf sediment. Geochim. Cosmochim. Acta 58, 1271-1284.

91. Ransom, B., Bennett, R.H., Baerwald, R. and Shea, K. 1997. TEM study of in situ organic matter on continental margins: occurrence and the "monolayer" hypothesis. Mar. Geol. 138, 1-9.

92. Ransom, B., Kim, D., Kastner, M. and Wainwright, S. 1998. Organic matter preservation on continental slopes: importance of mineralogy and surface area. Geochim. Cosmochim. Acta 62, 1329-1345.

93. Mayer, L.M. 1999. Extent of coverage of mineral surface by organic matter in marine sediments. Geochim. Cosmochim. Acta 63, 207-215.

94. Bock, M.J. and Mayer, L.M. 2000. Mesodensity organo-clay associations in a near-shore sediment. Mar. Geol. 163, 65-75.

95. Arnarson, T.S. and Keil, R.G. 2001. Organic-mineral interactions in marine sediments studied using density fractionation and X-ray photoelectron spectroscopy. Org. Geochem. 32, 1401-1415.

96. Wang, X.-C. and C. Lee. 1993. Adsorption and desorption of aliphatic amines, amino acids and acetate by clay minerals and marine sediments. Mar. Chem. 44, $1-23$

97. Keil, R.G., Montluçon, D.B., Prahl, F.G. and Hedges, J.I. 1994. Sorptive preservation of labile organic matter in marine sediments. Nature 370, 549-552.

98. Keil, R.G., Tsamakis, E., Giddings, J.C. and Hedges J.I. 1998. Biochemical distribution (amino acids, neutral sugars and lignin phenols) among size classes of modern marine sediments from the Washington Coast. Geochim Cosmochim. Acta 62, 1347-1364. 
99. Bergamaschi, B.A., Tsamakis, E., Keil, R.G., Eglinton, T., Montluçon, D.B. and Hedges, J.I. 1997. The effect of grain size and surface area on organic matter, lignin and carbohydrate concentrations and molecular compositions in Peru Margin sediments. Geochim. Cosmochim. Acta 61, 1247-1260.

100. Hedges, J.I., Hu, F.S., Devol, A.H., Hartnett, H.E., Tsamakis, E. and Keil, R.G 1999. Sedimentary organic matter preservation: a test for selective degradation under oxic conditions. Am. J. Sci. 299, 529-555

101. Knicker, H., Scaroni, A.W. and Hatcher, P.G. $1996 .{ }^{13} \mathrm{C}$ and ${ }^{15} \mathrm{~N}$ NMR spectroscopic investigation on the formation of fossil algal residues. Org. Geochem. 24 , 661-669.

102. Knicker, H. and Hatcher, P.G. 1997. Survival of protein in an organic-rich sediment: Possible protection by encapsulation in Organic Matter. Naturwissenschaften 84, 231-234.

103. Nguyen R.T., Harvey, H.R., Zanga, X van Heemsta, J.D.H., Hetényi, M. and Hatcher, P.G. 2003. Preservation of algaenan and proteinaceous material during the oxic decay of Botryococcus braunii as revealed by pyrolysis-gas chromatogthe oxic decay of Botryococcus braunii as revealed by pyrolysis-gas chromatography/m.

104. Wakeham, S.G., Peterson, M.L., Hedges, J.I., and Lee, C. 2002. Lipid biomarker fluxes in the Arabian Sea: with a comparison to the Equatorial Pacific Ocean Deep-Sea Res. II. 49, 2265-2301.

105.Lowenstam, H.A. and Weiner, S. 1989. On Biomineralization. Oxford University Press, New York. 324 pp.

106. Hecky, R.E., Mopper, K., Kilham, P. and Degens, E.T. 1973. The amino acid and sugar composition of diatom cell-walls. Mar. Biol. 19, 323-331.

107. Müller, P.J., Suess, E., and Ungerer, C.A. 1986. Amino acids and amino sugars of surface particulate and sediment trap material from waters of the Scotia Sea Deep-Sea Res. 33, 819-838.

108. Keil, R.G., Mayer, L.M., Quay, P.D., Richey, J.E. and Hedges, J.I. 1997. Loss of organic matter from riverine particles in deltas. Geochim. Cosmochim. Acta 61 , $1507-1511$

109. Hedges, J.I. and Keil, R.G. 1999. Organic geochemical perspectives on estuarine processes: sorption reactions and consequences. Mar. Chem. 65, 55-65.

110. Berner, R.A. 1995. Sedimentary organic matter preservation: an assessment and speculative synthesis - a comment. Mar. Chem. 49, 121-122.

11. Hill, P.S. 1998. Controls on floc size in the sea. Oceanography 11, 13-18.

112. Wakeham, S.G. and Canuel, E.A. 1988. Organic geochemistry of particulate matter in the eastern tropical North Pacific Ocean: Implications for particle dymatter in the eastern tropical Nor

113. Baldock, J.A. and Skjemstad, J. 2000. Role of soil matrix and minerals in protecting natural organic materials from degradation. Org. Geochem. 31, 697 710 .

114. Dignac, M. -F., Ginestet, P., Rybacki, D., Bruchet, A., Urbain,V. and Scribe, P. 2000. Fate of wastewater organic pollution during activated sludge treatment: Nature of residual organic matter. Water Res. 34, 4185-4194.

115. Dignac, M. -F., Derenne, S., Ginestet, P., Bruchet, A., Knicker, H. and Largeau, C. 2000 . Determination of structure and origin of refractory organic matter in bio-epurated wastewater via spectroscopic methods. Comparison of conventionbio-epurated wastewater via spectroscopic methods. Comparison of

116. The authors wish to thank the Oceanography Division of the U.S. National Science Foundation for supporting decades of study of particle flux and composition, and the Hanse Wissenschaftskolleg (Delmenhorst, Germany) for the opportunity to collaborate on this work as a Research Group in May, 2003. We also thank our silent Research Group member, John Hedges, for his organic matter wisdom over the years. Larry Mayer, John Farrington, and Rob Armstrong provided constructive reviews of the manuscript and useful comments.
Cindy Lee received her PhD in chemical oceanography in 1975 from the Scripps Institution of Oceanography at the University of California in San Diego. She then spent 11 years at the Woods Hole Oceanographic Institution working in the field of marine organic geochemistry. Since 1986 she has been on the faculty at Stony Brook University's Marine Sciences Research Center where she is a SUNY Distinguished Professor. She is a Fellow of the American Geophysical Union and the Geochemical Society, and is President-Elect of AGU's Ocean Sciences Section. She has written over 100 papers on the distribution and behavior of biogenic organic compounds in the marine environment, in particular the rates and mechanisms of reactions that occur as these compounds undergo alteration. Her address: Marine Sciences Research Center, Stony Brook University, Stony Brook, NY 11794-5000, USA. cindy.lee@sunysb.edu

Stuart Wakeham earned his PhD in chemistry at the University of Washington in 1976. He was a postdoctoral investigator at the Swiss Federal Institute of Technology (EAWAG) and then spent 9 years at Woods Hole Oceanographic Institution. Since 1987, he has been at the Skidaway Institute of Oceanography (Savannah, GA). In 2003, he was a Fellow at the Hanse Institute for Advanced Study, Delmenhorst, Germany. His research involves application of biomarkers and isotopes for studying the cycling of organic matter in aquatic environments. His address: Skidaway Institute of Oceanography, 10 Ocean Science Circle, Savannah, GA 31411, USA. stuart@skio.peachnet.edu

Carol Arnosti earned a PhD in chemical oceanography from the WHOI/M.I.T. Joint Program in Oceanography. She was a Fulbright postdoc at the Max-Planck Institute for Marine Microbiology, Bremen, Germany, and is now an associate professor in the Department of Marine Sciences at the University of North Carolina-Chapel Hill. From 2001-2002, she was a Fellow at the Hanse Institute for Advanced Study (Delmenhorst, Germany). Her research focuses on the structure and reactivity of organic macromolecules, and the roles of bacterial communities in organic matter degradation. Her address: Department of Marine Sciences, 12-7 Venable Hall, СВ \#3300, University of North Carolina, Chapel Hill, NC 27599, USA.

arnosti@email.unc.edu 